Original Research Paper

\title{
Elemental Composition and Concentration of Atmospheric Particulate Matter in Kuwait
}

\author{
${ }^{1}$ Jasem M. Al-Awadhi and ${ }^{2}$ Anwar B. Al-Helal \\ ${ }^{I}$ Department of Earth and Environmental Sciences, Faculty of Science, Kuwait University, \\ P.O. Box 5969, 13060 Safat, Kuwait \\ ${ }^{2}$ Department of Science, Public Authority for Applied Education and Training, College of Basic Education, Kuwait
}

\author{
Article history \\ Received: 02-07-2016 \\ Revised: 30-11-2016 \\ Accepted: 30-01-2017 \\ Corresponding author: \\ Jasem M. Al-Awadhi \\ Department of Earth and \\ Environmental Sciences, \\ Faculty of Science, Kuwait \\ University, P.O. Box 5969, \\ 13060 Safat, Kuwait \\ Email: jawadhi1@live.com
}

\begin{abstract}
Hourly $\mathrm{PM}_{10}$ and $\mathrm{PM}_{2.5}$ samples were simultaneously collected at 10 and 3 urban sites, respectively in Kuwait from March 2014 to February 2015, to study the air quality and heavy metals content and Total Petroleum Hydrocarbons (TPHs) in $\mathrm{PM}_{10}$ samples. The annual average concentrations of $\mathrm{PM}_{10}$ and $\mathrm{PM}_{2.5}$ were 152 and $97.3 \mu \mathrm{g} / \mathrm{m}^{3}$, respectively, with an average $\mathrm{PM}_{2.5} / \mathrm{PM}_{10}$ ratio of $70 \%$. The contamination level of heavy metals in $\mathrm{PM}_{10}$ samples was assessed in terms of Enrichment Factor (EF) using mathematical models. The elements associated with an anthropogenic activity in the $\mathrm{PM}_{10}$ samples; i.e., $\mathrm{Pb}, \mathrm{Cu}, \mathrm{Co}, \mathrm{Cd}$ and $\mathrm{Zn}$, were 2.4, 12.9, 14.6, 42.6 and 156.2 times higher than the corresponding background values in Kuwait soil. TPH was the dominant pollutant in the $\mathrm{PM}_{10}$ samples. In general, most daily average Air Quality Indices (AQI) of $\mathrm{PM}_{10}$ concentrations fell under the categories of "good" and "moderate".
\end{abstract}

Keywords: $\mathrm{PM}_{10}, \mathrm{PM}_{2.5}$, Heavy Metals, TPHs

\section{Introduction}

Atmospheric particulate Matter (PM) consists of a mixture of solid particles and liquid droplets from a variety of sources and can be divided according to particulate size into dust fall (with an aerodynamic diameter of 100-1000 $\mu \mathrm{m}$ ), Total Suspended Particulate (TSP, with an aerodynamic diameter of less than 100 $\mu \mathrm{m})$, inhalable particulate matter $\left(\mathrm{PM}_{10}\right.$, with an aerodynamic diameter of less than $10 \mu \mathrm{m})$, coarse particulate $\left(\mathrm{PM}_{2.5-10}\right.$, with an aerodynamic diameter of 2.5-10 $\mu \mathrm{m})$ and fine particulate $\left(\mathrm{PM}_{2.5}\right.$, with an aerodynamic diameter of less than $2.5 \mu \mathrm{m})$ (SEP, 2003). In general $\mathrm{PM}_{10}$ originates from mineral dust, while $\mathrm{PM}_{2.5}$ and finer PM, which have more serious health effects compared to coarser PM, have various sources, normally dominated by combustion.

PM is composed of various heavy metal elements, most of them having toxic effects that have been extensively studied in urban areas. The determination of heavy metal element concentrations in the ambient suspended particulate matter of major urban areas is an important component of pollution studies (Goyer, 1996; Donaldson and MacNee, 1998; Singh, 2001). Windblown dust generally contributes to the release of heavy metals in the ambient atmosphere (USEPA, 1999a;
AMAP, 1997). Hazardous suspended PM pollutants are released by various sources like factories, refineries, automobiles, power plants, sewage plants, etc. (Dannecker et al., 1990). Pollution of this nature is a worldwide problem, including in Kuwait's urban areas, since these metals persist in the environment and most of them are toxic to living organisms. Although considered essential for various human biological functions in trace quantities, several of these heavy metals pose serious toxicological risks at high levels (Addo et al., 2012).

Emissions of PM in Kuwait have been increasing remarkably in the past two decades; thus, it has become a problem of significant concern (Al-Awadhi and Al-Awadhi, 2006; KEPA, 2014). The PM levels in Kuwait's cities have been on the rise, attributable to a significant increase in vehicular traffic-the number of vehicles in 2004 was 1.042 million, whereas this number reached to 1.916 million in 2014 (KEPA, 2014). Traffic remains the main source of air pollution in Kuwait's cities, while upstream/downstream industrial sources such as power plants, oil fields and various other industries contribute to a much lesser degree (Al-Salem and Khan, 2008). Table 1 shows the total $\mathrm{PM}_{10}$ and $\mathrm{PM}_{2.5}$ emission rates from various sources in Kuwait city. 
Although real-time monitoring of suspended PM is a vital means for predicting pollution levels, it does not describe the composition of the pollution. Accordingly, this study aims to investigate the air quality at ten sites in Kuwait, in terms of concentrations of suspended PM $\left(\mathrm{PM}_{10}\right.$ and $\left.\mathrm{PM}_{2.5}\right)$ and the elemental composition of $\mathrm{PM}_{10}$ in terms of heavy metals. The measured $\mathrm{PM}_{10}$ levels are compared with the Kuwait Environment Public Authority (K-EPA) guideline limits.

\section{Prototype Data Collection}

The $\mathrm{PM}_{10}$ and $\mathrm{PM}_{2.5}$ data were collected from ten and three Air Quality Monitoring (AQM) stations, respectively, set up by K-EPA, using Met-One (USA) Model Beta Attenuation Mass (BAM)-1022 monitors. Continuous measurements of $\mathrm{PM}_{10}$ and $\mathrm{PM}_{2.5}$, corresponding to a period between March 1st, 2014 and February 28th, 2015 (i.e., 12 months), were collected. For correlation purpose, the major meteorological parameters, including wind speed $\mathrm{m} / \mathrm{s}$ ) and direction (degrees), relative humidity $(\%)$ and ambient temperature $\left({ }^{\circ} \mathrm{C}\right)$, were also obtained from the AQM stations (Gill Instruments, UK) over the same monitoring period. The monitoring stations for $\mathrm{PM}_{10}$ are: Mutla (MU), Al-Jahra (J), Saad Al-Abdullah (SA), Shuwaikh (SH), Mansuria (MA), Al-Salam (S), Rumaithiya (R), Al-Ahmadi (A), Fahaheel (F) and Ali AlSalem (AS) (Fig. 1), while the monitoring stations for $\mathrm{PM}_{2.5}$ are: Al-Jahra (J), Saad Al-Abdullah (SA) and AlAhmadi (A). Each of these stations is located in a residential area which differs in its surroundings, geographical characteristics and sources of air pollution.
Each station is provided with a continuous gas monitor. The monitors are operated automatically and measurements are normally recorded every five minutes continuously, $24 \mathrm{~h}$ a day, throughout the year. PM concentrations are measured by the beta-gauge method. A span calibration is used to check the validity of the data, where a sample of known concentration of pollutants is tested by the machine. This is done every three to four days to check for the behavior and accuracy of the monitors. Also, full system checks are routinely carried out once every three months by specialists.

Ambient PM measurements were retrieved from a central online data acquisition system managed and controlled by EnviDAS software. The data was filtered manually by discarding NULL values and the total percentage of filtered data recorded was about $96.5 \%$ : i.e., $3.5 \%$ of the data values were cleaned), which is considered an acceptable percentage of data recovery for air quality assessment (Khan and Al-Salem, 2007).

Table 1. Total $\mathrm{PM}_{10}$ and $\mathrm{PM}_{2.5}$ emission rates from various sources in Kuwait city (ton/year)

\begin{tabular}{lll}
\hline Source & $\mathrm{PM}_{2.5}$ & $\mathrm{PM}_{10}$ \\
\hline Transport & 9,750 & 11,450 \\
Aviation & 50 & 50 \\
Port & 150 & 200 \\
Road dust & 7,000 & 46,650 \\
Power plants & 1,400 & 1,700 \\
Industries & 900 & 1,100 \\
Gathering centers & 1,000 & 100 \\
Total & 19,350 & 61,250 \\
\hline
\end{tabular}

Source: KEPA (2014)

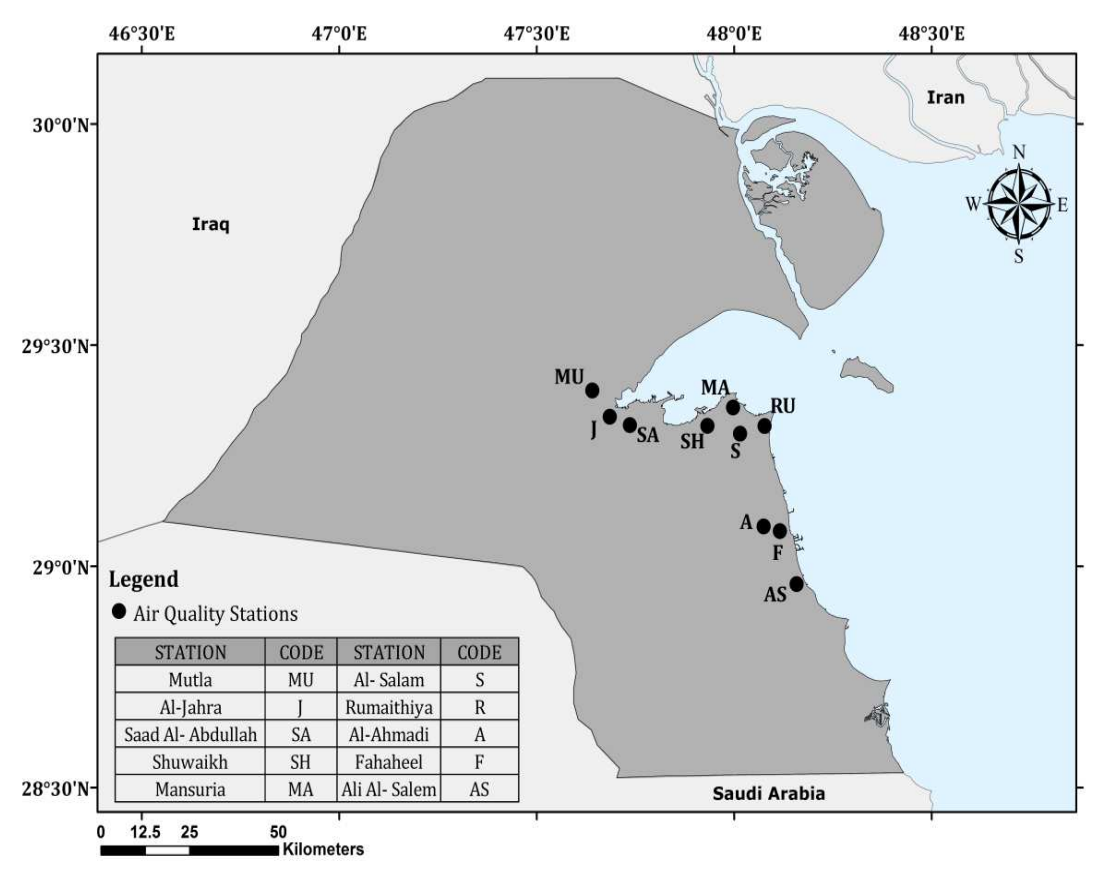

Fig. 1. Locations of the air quality monitoring stations set up by K-EPA 
Fifteen $\mathrm{PM}_{10}$ filters were collected from the ten stations for a preliminary quantification of the metal content. Five duplicate samples were collected from J, $\mathrm{SH}, \mathrm{F}, \mathrm{Mu}$ and A stations. The collections were carried out on two different days: May 1st and 7th, 2014.

\section{Methodology}

Inductively Coupled Plasma Optical Emission Spectrometry (ICPOES) was used for determining element presence in $15 \mathrm{PM}_{10}$ samples. The sample containers (PTFE flasks) were soaked overnight with $10 \% \mathrm{HNO}_{3}$, followed by rinsing thrice with the same acid and thrice with de-ionized water and finally dried in an oven at $50^{\circ} \mathrm{C}$. For chemical analysis, the extraction and analysis of heavy metals was carried out as per the US EPA method IO-3.2 (USEPA, 1999b). As per the method, $\mathrm{PM}_{10}$ samples collected on glass fiber, along with their respective blank filter papers (1 blank per sample), was digested by Mars 6 Microwave Digestion system using aquaregia $(3 \mathrm{HCl}+1 \mathrm{HNO})$ for $23 \mathrm{~min}$ at about $180^{\circ} \mathrm{C}$. After digestion the solutions were neutralized with $2 \%$ boric acid and gauged. The advantage of using hydrochloric acid is the dissolution of the quartz filter, which avoids the need for filtration. Field blanks and certified urban dust (NIST 1648) were digested and analyzed along with the samples. For quality assurance, only samples with a recovery value $>95 \%$ were considered for analysis, ensuring the precision and reproducibility of the measurements.

Total Petroleum Hydrocarbons (TPHs) in the $\mathrm{PM}_{10}$ samples were measured using the US-EPA 8015C method (GC analysis) and US-EPA 3540C (Extraction) procedure. The filter samples containing particulates matters were extracted on Soxhlet Extraction unit (7890A GC system with flame Ionization DetectorAgilent) for $4 \mathrm{~h}$ with $60 \mathrm{~mL}$ dichloromethane, filtered with hexane, concentrated to $1 \mathrm{~mL}$ and analyzed on $\mathrm{GC}$ system equipped with fused silica capillary column, operated in split mode using carrier gas, helium. Then, the samples were heated at $50^{\circ} \mathrm{C}$ and gradually increased through 3 ramps up to $330^{\circ} \mathrm{C}$. The $\mathrm{GC}$ system was calibrated using C8-C40 standards from 175 to $1750 \mu \mathrm{g}$ $\mathrm{mL}^{-1}$ and the samples were quantitated against the curve generated through calibration.

The Enrichment Factor (EF) equation (Sutherland, 2000) was employed for calculating the level of PM contamination by heavy elements:

$$
\begin{aligned}
& E F=\left[C_{n}(\text { sample }) / C_{\text {ref }}(\text { sample })\right] / \\
& {\left[B_{n}(\text { baseline }) / B_{\text {ref }}(\text { baseline })\right]}
\end{aligned}
$$

Where:

$C_{n}$ (sample) $=$ The content of the examined element in the PM sample

$C_{r e f}($ sample $)=$ The content of the reference element in the PM

$B_{n}$ (baseline) $=$ The baseline content of the examined element in Kuwait soils

$B_{\text {ref }}($ baseline $)=$ The baseline content of the reference element in Kuwait soils

The persistency of pollutant exceedances; hourly, daily and monthly averages; pollutant ratios $\left(\mathrm{PM}_{2.5} / \mathrm{PM}_{10}\right)$ and correlation coefficients between various locations and PMs were investigated using the SPSS software package (Version 19).

Air quality in terms of $\mathrm{PM}_{10}$ was also assessed through the use of the Air Quality Index (AQI) developed by Al-Shayji et al. (2008), for Kuwait, based on the guidelines proposed by the US Environmental Protection Agency (USEPA, 2006). Table 2 shows the AQI category codes, suggested for the Kuwait EPA and their ranges for $\mathrm{PM}_{10}$, based on health effects.

Table 2. AQI range (after Al-Shayji et al. (2008) and the US Environmental Protection Agency (2006)

\begin{tabular}{lll}
\hline Categories & AQI sub-index & $\begin{array}{l}\mathrm{PM}_{10}\left(\mu \mathrm{g} / \mathrm{m}^{3}\right) \\
24 \mathrm{~h}\end{array}$ \\
\hline Good & $0-50$ & $0.0-90^{\mathrm{a}}$ \\
Moderate & $51-100$ & $\begin{array}{l}0-54)^{\mathrm{b}} \\
90.1-350.0 \\
(55-154)\end{array}$ \\
Unhealthy for sensitive groups & $101-150$ & $350.1-431.3$ \\
Unhealthy & & $(155-254)$ \\
Very Unhealthy & $151-200$ & $431.4-512.5$ \\
& & $(255-354)$ \\
Hazardous1 & $201-300$ & $512.6-675.0$ \\
& & $(355-424)$ \\
Hazardous2 & $301-400$ & $675.1-837.5$ \\
& & $(425-504)$ \\
\end{tabular}




\section{Results}

\section{Basic Analysis for $P M_{10}$}

Table 3 describes the statistic of average all measured concentration of $\mathrm{PM}_{10}$. The results indicate that the variation in the $\mathrm{PM}_{10}$ concentrations ranges between 5 and $9.6 \%$ and the mean values are greater than the median values having positive skewness values, i.e., values approaching to zero from the positive direction. Thus under these circumstances, $\mathrm{PM}_{10}$ pollutants can be considered as a stable condition.

The range of the two percentile points, defining the upper and lower tails of data, indicates a clear difference between the maximum and minimum measured values. Such difference is also shown in the inter quartile (difference between the 75th and 25th percentile) and the skewness number indicates that the data deviates from symmetry around the mean, while positive kurtosis value indicates a shape flatter of data than normal.

\section{The Arithmetic Mean Concentration}

The monthly average concentrations of $\mathrm{PM}_{10}$ at each station are shown in Fig. 2. It is noticed that SA station has the maximum monthly average concentration among all stations, with a concentration of $387.5 \mu \mathrm{g} / \mathrm{m}^{3}$, which is 1.1 to 2.5 times higher than at other stations. The monthly average concentration at the 10 stations varied from $23.1 \mu \mathrm{g} / \mathrm{m}^{3}$ (in November) to $387.5 \mu \mathrm{g} / \mathrm{m}^{3}$ (in February), with an average of $152 \mu \mathrm{g} / \mathrm{m}^{3}$ (Fig. 3). The highest concentration observed in February deviates from the normal trend associated with dusty days, which peak annually in June. The concentrations by season varied from $107 \mu \mathrm{g} / \mathrm{m}^{3}$ (autumn) to 173-174 $\mu \mathrm{g} / \mathrm{m}^{3}$ (spring and summer). High $\mathrm{PM}_{10}$ concentrations in summer can be attributed to the effects of northwesterly winds, which carry dust from the Iraqi Desert into Kuwait. High winter averages for $\mathrm{PM}_{2.5}$ and $\mathrm{PM}_{10}$ occur due to various factors that account for elevated amounts of $\mathrm{PM}_{10}$ in that season, such as the noticeable increase in the traffic volume due to the influx of workers and students during winter season; moreover, the normal lower mixing heights with stable boundary layers (inversion layer) during the winter season, results in trapping more PM and limiting its dispersion in the atmosphere. The annual average $\mathrm{PM}_{10}$ concentration for Kuwait's cities reached $152.2 \mu \mathrm{g} / \mathrm{m}^{3}$, with minimum and maximum concentrations of $112.0 \mu \mathrm{g} / \mathrm{m}^{3}(\mathrm{~J})$ and 190.5 $\mu \mathrm{g} / \mathrm{m}^{3}$ (AS), respectively.

\section{Exceedance of $P M_{10}$ Permissible Limits}

A comparison between the daily mean concentrations and applicable air quality standards promulgated by K-EPA $\left(350 \mu \mathrm{g} / \mathrm{m}^{3}\right)$ for residential areas and the proposed standard $\left(150 \mu \mathrm{g} / \mathrm{m}^{3}\right)$ reveals that the data in all monitoring stations exceeded the permissible limits. With respect to effective K-EPA rules and regulations $\left(350 \mu \mathrm{g} / \mathrm{m}^{3}\right)$, the percentage of data exceeding the limit at the 10 stations varied from 3.3 to $10.1 \%$, with an average of $6.7 \%$, while on the proposed value by K-EPA $\left(150 \mu \mathrm{g} / \mathrm{m}^{3}\right)$, the percentage of data exceeding the limit at the 10 stations varied from 15.3 to $34.0 \%$, with an average of $26.2 \%$ (Fig. 4). On average, 24 and 96 exceedances were recorded per year during the period between March 1st, 2014 and February 28th, 2015 applying $\mathrm{PM}_{10}$ standard values of 350 and $150 \mu \mathrm{g} / \mathrm{m}^{3}$, respectively. Considering the proposed $\mathrm{PM}_{10}$ permissible limit of $150 \mu \mathrm{g} / \mathrm{m}^{3}$, the total average percentage of exceedances during spring, summer, fall and winter were 28.4, 37.8, 13.5 and $24.9 \%$, respectively. Note that highly elevated levels of $\mathrm{PM}_{10}$ are known to occur in Kuwait (mainly in summer) resulting in a reduction of visibility (Al-Hajraf et al., 2005). The annual limit value of 90 $\mu \mathrm{g} / \mathrm{m}^{3}$, specified by K-EPA, was exceeded at all monitoring stations over the 12 months of monitoring. The annual mean concentration averaged over all 10 stations was $152.2 \mu \mathrm{g} / \mathrm{m}^{3}$.

Table 3. Statistic descriptive of PM10 concentration $\left(\mu \mathrm{g} / \mathrm{m}^{3}\right)$ at the 10 stations during March 2014 to February 2015

\begin{tabular}{|c|c|c|c|c|c|c|c|c|c|c|c|c|c|c|c|}
\hline \multirow[b]{3}{*}{ Location } & \multirow[b]{3}{*}{ Mean } & \multicolumn{2}{|c|}{$\begin{array}{l}95 \% \text { Confidence } \\
\text { Interval for Mean }\end{array}$} & \multirow{3}{*}{$\begin{array}{l}5 \% \\
\text { Trimmed } \\
\text { Mean }\end{array}$} & \multirow{3}{*}{ Median } & \multirow[b]{3}{*}{ Variance } & \multirow{3}{*}{$\begin{array}{l}\text { Std. } \\
\text { Deviation }\end{array}$} & \multirow[b]{3}{*}{ Minimum } & \multirow[b]{3}{*}{ Maximum } & \multirow[b]{3}{*}{ Range } & \multirow{3}{*}{$\begin{array}{l}\text { Interquartile } \\
\text { Range }\end{array}$} & \multirow[b]{3}{*}{ Skewness } & \multirow[b]{3}{*}{ Kurtosis } & \multirow{3}{*}{$\begin{array}{l}25^{\text {th }} \\
\text { Percentile }\end{array}$} & \multirow{3}{*}{$\begin{array}{l}75 \text { th } \\
\text { Percentile }\end{array}$} \\
\hline & & Lower & Upper & & & & & & & & & & & & \\
\hline & & Bound & Bound & & & & & & & & & & & & \\
\hline$\overline{\mathrm{MU}}$ & 130.4 & 125.4 & 135.4 & 98.4 & 73.0 & 53948.8 & 232.3 & 1.0 & 4274.0 & 4273.0 & 86.0 & 9.0 & 107.9 & 48.0 & 134.0 \\
\hline $\mathrm{J}$ & 111.9 & 108.6 & 115.3 & 89.4 & 77.0 & 25469.7 & 159.6 & 1.0 & 4064.0 & 4063.0 & 52.0 & 9.7 & 144.9 & 58.0 & 110.0 \\
\hline SA & 143.3 & 136.0 & 150.6 & 95.3 & 78.0 & 117280.1 & 342.5 & 1.0 & 7946.0 & 7945.0 & 98.0 & 9.9 & 135.6 & 37.0 & 135.0 \\
\hline SH & 154.8 & 150.8 & 158.8 & 129.5 & 111.0 & 35414.3 & 188.2 & 2.0 & 3538.0 & 3536.0 & 86.0 & 7.9 & 94.3 & 81.0 & 167.0 \\
\hline MA & 170.8 & 163.8 & 177.8 & 126.4 & 108.0 & 98710.9 & 314.2 & 1.0 & 6135.0 & 6134.0 & 98.0 & 9.1 & 109.9 & 70.0 & 168.0 \\
\hline S & 183.3 & 176.3 & 190.3 & 135.2 & 113.0 & 110963.9 & 333.1 & 9.0 & 6827.0 & 6818.0 & 93.5 & 9.0 & 108.6 & 79.0 & 172.5 \\
\hline $\mathrm{R}$ & 141.5 & 137.6 & 145.5 & 118.2 & 83.5 & 34613.8 & 186.0 & 1.0 & 4399.0 & 4398.0 & 88.0 & 7.6 & 108.7 & 56.0 & 144.0 \\
\hline A & 175.3 & 168.2 & 182.3 & 132.3 & 118.0 & 101224.1 & 318.2 & 2.0 & 8045.0 & 8043.0 & 97.0 & 10.3 & 154.9 & 76.0 & 173.0 \\
\hline F & 123.7 & 119.1 & 128.3 & 93.8 & 83.0 & 47366.7 & 217.6 & 1.0 & 4546.0 & 4545.0 & 63.0 & 9.4 & 115.6 & 57.0 & 120.0 \\
\hline AS & 189.7 & 182.2 & 197.2 & 138.6 & 116.0 & 122964.1 & 350.7 & 12.0 & 4994.0 & 4982.0 & 95.0 & 8.1 & 80.5 & 80.0 & 175.0 \\
\hline
\end{tabular}
difference is also shown in the inter quartile (difference between the 75 th and 25 th percentile) and the skewness number indicates that the data deviates from symmetry around the mean, while positive kurtosis value indicates a shape flatter of data than normal 


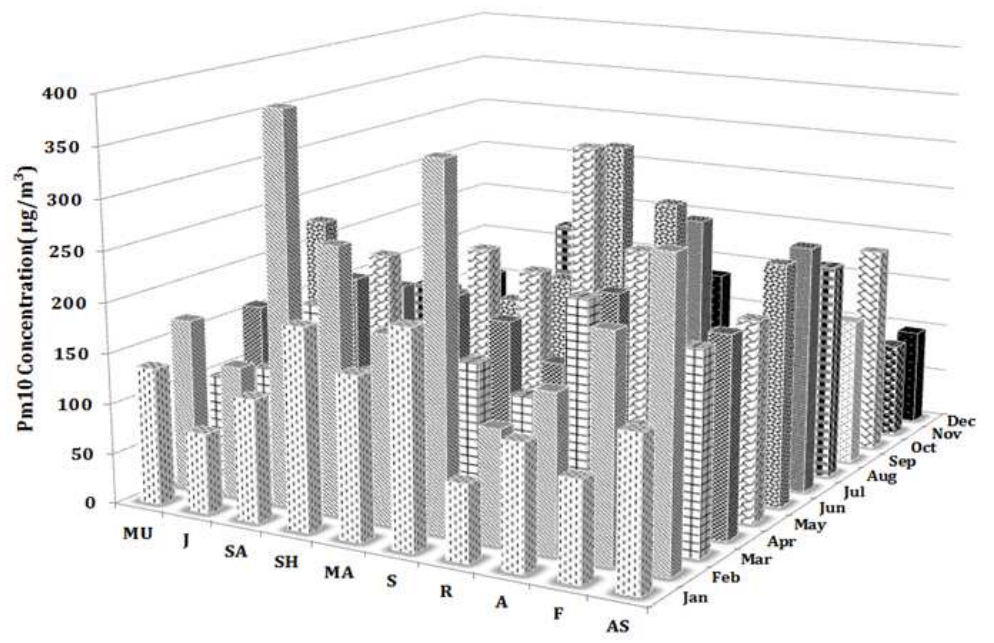

Fig. 2. Monthly average concentration of $\mathrm{PM}_{10}$ at the $\mathrm{AQM}$ stations

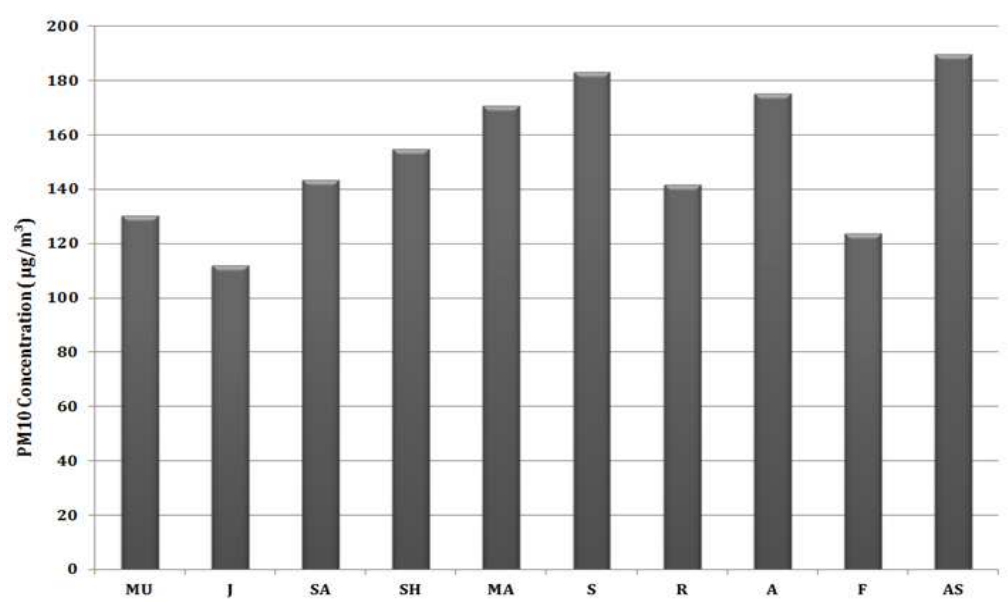

Fig. 3. Annual average concentration of $\mathrm{PM}_{10}$ at the $\mathrm{AQM}$ stations

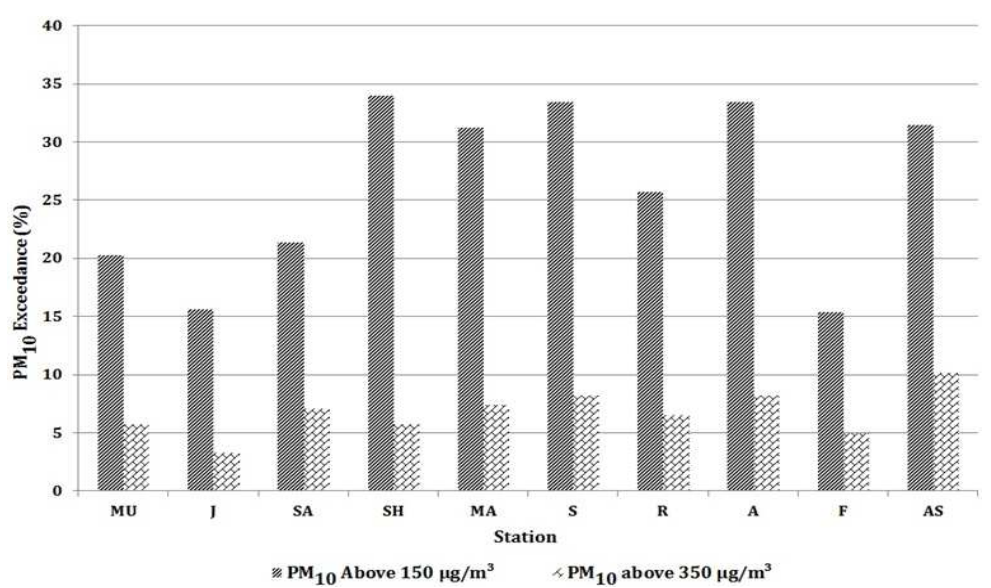

Fig. 4. Percentages of $\mathrm{PM}_{10}$ exceedances of effective and proposed permissible limits promulgated by K-EPA during the monitoring period at the 10 stations 


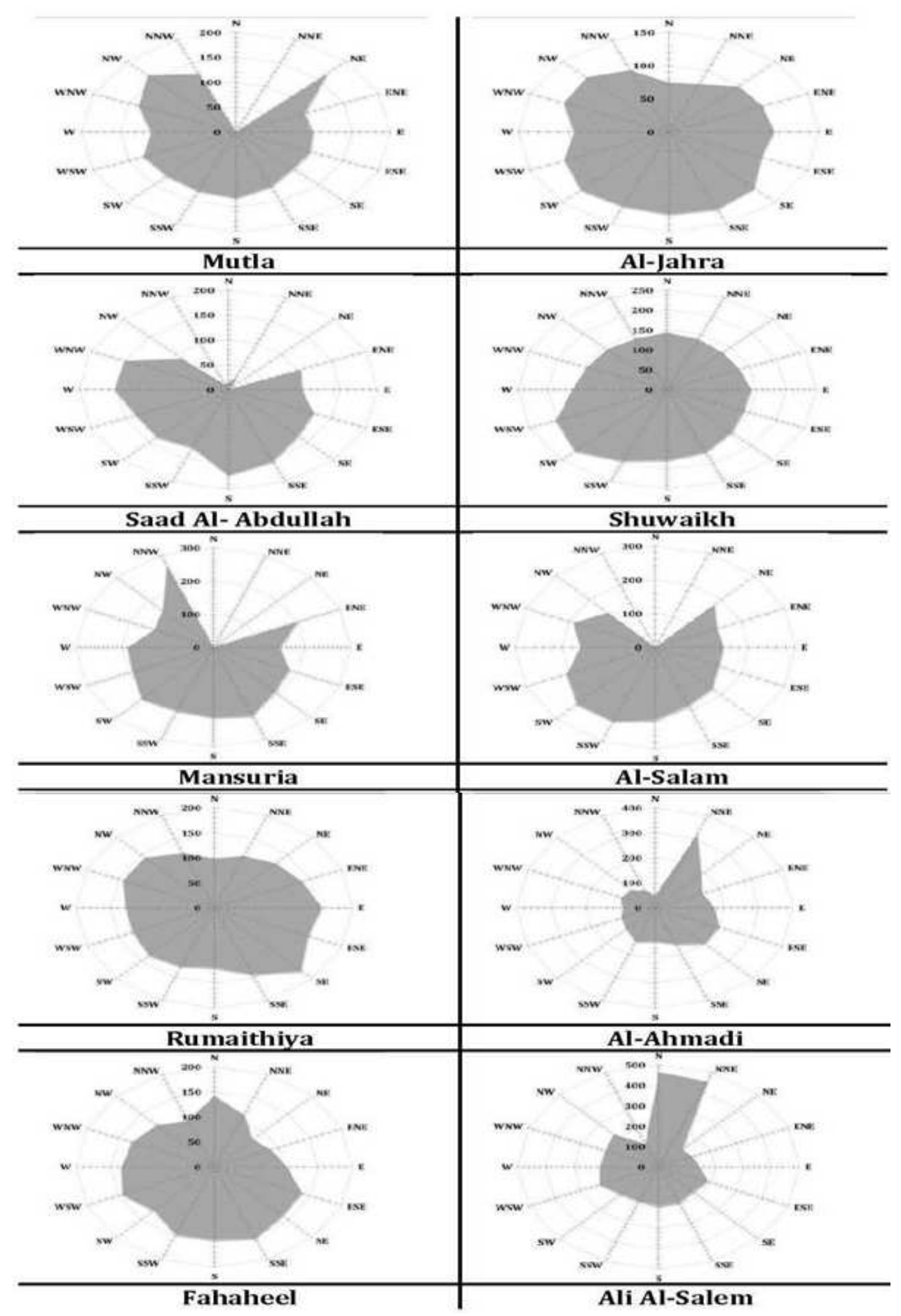

Fig. 5. Annual mean $\mathrm{PM}_{10}$ concentration roses for all monitoring stations

Annual mean $\mathrm{PM}_{10}$ concentration roses were constructed with 16 wind directions in order to investigate the relative contributions of winds blowing $\mathrm{PM}_{10}$ from each direction (Fig. 5). The plots revealed that winds blowing $\mathrm{PM}_{10}$ came predominantly from between the northwest and south-west corridors at the monitoring stations located near the edge of the open desert (i.e., MU, SA and AS). This suggests that dust potentially contributes to the ambient $\mathrm{PM}_{10}$ load in these open areas. Rising/suspended dust and dust storms in Kuwait are generated by the prevailing northwesterly winds, representing $60 \%$ of wind-direction 
measurements taken in Kuwait; moreover, these winds are dominant in the summer season (Al-Basri, 1993). On the other hand, the stations that are located in the inner cities (i.e., R, SH, F and J), were subjected to $\mathrm{PM}_{10}$ blowing in from all directions with generally elevated levels from the southwest side. In Ahmedi station (A), located to the east of the Burgan oil field, winds blowing $\mathrm{PM}_{10}$ came predominantly from the northeast and southeast corridors, suggesting that $\mathrm{PM}_{10}$ from the oil field contributes significantly to the ambient load in this area.

The concentrations of $\mathrm{PM}_{10}$ at all stations showed a high correlation, ranging from 0.91 to $0.03(r=$ 0.75) (Table 4), implying that $\mathrm{PM}_{10}$ may have common sources, such as traffic, at all stations. The highest correlation occurred between Ahmadi (A) and Ali Al-Salem (AS); these two areas are located near the boundary of the Shuaiba petro-industrial area and the Burgan oil field. Shuwaikh (SH), which is located in the seaport zone near Kuwait city, at a distance of approximately $100 \mathrm{~km}$ from these two areas, showed a lower correlation with $\mathrm{A}$ and $\mathrm{AS}$, i.e., 0.8 and 0.4 , respectively. The prevailing northwesterly winds are likely to influence the diffusion of $\mathrm{PM}_{10}$ concentrations generated from the petro-industrial area away from the other sites:

- Correlation is significant at the 0.05 level (twotailed)

- Correlation is significant at the 0.01 level (twotailed)

\section{Variation of $P M_{10}$ Levels during the Day}

The evolution of hourly pollutant concentrations measured during the day is presented in Fig. 6a and 6b. Figure $6 \mathrm{a}$ indicates that an elevation in concentrations occurs during noontime and around midnight. Similarly, Fig. $6 \mathrm{~b}$ confirms that this finding is applicable during all months. The noontime elevation may be a result of a substantial secondary component beside the exhaust component, such as suspended dust. The midnight elevation may be associated with the inversion layer behavior during the midnight hours (cooling time) resulting in limited dispersion of pollutants and increasing the potentiality of trapping them the air atmosphere; this is due to the relatively calmer conditions from around midnight until the early morning hours favoring the accumulation of pollutants and causing them to reach the ground.

Figure 7 shows an inverse correlation between the hourly average variation in relative humidity and $\mathrm{PM}_{10}$ concentration. This indicates that as the humidity increases, the potentiality of $\mathrm{PM}_{10}$ emissions from various sources reduces. Figure 8 shows a positive correlation between the hourly average variation in temperature and $\mathrm{PM}_{10}$ concentration, suggesting that high temperatures during the day impact $\mathrm{PM}_{10}$ pollution levels in the air. These high temperatures play a major role in rising convective motions, turbulent flows and atmospheric diffusion capacity in the lower part of the atmosphere and as a consequence higher emissions of fine particles is achieved.

\section{Ambient Concentrations of $P M_{2.5}$}

The variation in $\mathrm{PM}_{2.5}$ concentrations during the data collecting period is presented in Table 5; these range from 47.1 to $177.1 \mu \mathrm{g} / \mathrm{m}^{3}$ at three monitoring stations (A, J and SA), with an average concentration of $97.3 \mu \mathrm{g} / \mathrm{m}^{3}$. These measurements are 4.7 and 17.7 times more than the annual US NAAQS standard of $\mathrm{PM}_{2.5}\left(10 \mu \mathrm{g} / \mathrm{m}^{3}\right)$, respectively (Fig. 9). The results obviously indicate that fine PM should be seriously considered as a health impact factor in Kuwait's urban areas. Hourly averages of $\mathrm{PM}_{10}$ and $\mathrm{PM}_{2.5}$ pollutants show that both pollutants follow a relatively similar trend of variations during a day (Fig. 10). The calculated ratios of $\mathrm{PM}_{2.5} / \mathrm{PM}_{10}$ varied spatially, ranging from 0.31 to 1.4 with an average of 0.7 , indicating that fine PM at urban sites is also a concerning problem.

Table 4. Correlation coefficient (r) of $\mathrm{PM}_{10}$ between the sites

\begin{tabular}{|c|c|c|c|c|c|c|c|c|c|c|}
\hline & $\mathrm{Mu}$ & $\mathrm{J}$ & SA & $\mathrm{SH}$ & MA & $\mathrm{S}$ & $\mathrm{R}$ & A & $\mathrm{F}$ & AS \\
\hline$\overline{\mathrm{MU}}$ & 1.000 & & & & & & & & & \\
\hline $\mathrm{J}$ & $0.552^{* *}$ & 1.000 & & & & & & & & \\
\hline SA & $0.695^{* *}$ & $0.789^{* *}$ & 1.000 & & & & & & & \\
\hline SH & 0.200 & $0.470^{*}$ & 0.300 & 1.000 & & & & & & \\
\hline MA & -0.300 & 0.100 & 0.000 & 0.300 & 1.0 & & & & & \\
\hline S & $0.713^{* *}$ & $0.441^{*}$ & $0.470^{*}$ & $0.435^{*}$ & 0.2 & 1.000 & & & & \\
\hline $\mathrm{R}$ & 0.300 & 0.200 & 0.300 & -0.100 & 0.3 & $0.487^{*}$ & 1.000 & & & \\
\hline A & $0.729^{* *}$ & 0.400 & $0.554^{* *}$ & -0.100 & 0.0 & $0.761^{* *}$ & $0.636^{* *}$ & 1.0 & & \\
\hline $\mathrm{F}$ & $0.781^{* *}$ & $0.531^{* *}$ & $0.601^{* *}$ & 0.400 & -0.1 & $0.762^{* *}$ & 0.300 & $0.649^{* *}$ & 1.000 & \\
\hline AS & $0.609^{* *}$ & 0.300 & $0.430^{*}$ & 0.000 & 0.2 & $0.796^{* *}$ & $0.686^{* *}$ & $0.909^{* *}$ & $0.594^{* *}$ & 1.0 \\
\hline
\end{tabular}

* Correlation is significant at the 0.05 level (two-tailed)

** Correlation is significant at the 0.01 level (two-tailed) 
Jasem M. Al-Awadhi and Anwar B. Al-Helal / American Journal of Environmental Sciences 2017, 13 (1): 77.92 DOI: 10.3844/ajessp.2017.77.92

Table 5. Statistical descriptive of measured of PM2.5 concentration $(\mu \mathrm{g} / \mathrm{m} 3)$ at the monitored sites

\begin{tabular}{|c|c|c|c|c|c|c|c|c|c|c|c|c|c|c|c|}
\hline \multirow[b]{3}{*}{ Location } & \multirow[b]{3}{*}{ Mean } & \multicolumn{2}{|c|}{$\begin{array}{l}95 \% \text { Confidence } \\
\text { Interval for Mean }\end{array}$} & \multirow{3}{*}{$\begin{array}{l}5 \% \\
\text { Trimmed } \\
\text { Mean }\end{array}$} & \multirow{3}{*}{ Median } & \multirow[b]{3}{*}{ Variance } & \multirow{3}{*}{$\begin{array}{l}\text { Std. } \\
\text { Deviation }\end{array}$} & \multirow[b]{3}{*}{ Minimum } & \multirow[b]{3}{*}{ Maximum } & \multirow[b]{3}{*}{ Range } & \multirow{3}{*}{$\begin{array}{l}\text { Interquartile } \\
\text { Range }\end{array}$} & \multirow[b]{3}{*}{ Skewness } & \multirow[b]{3}{*}{ Kurtosis } & \multirow{3}{*}{$\begin{array}{l}\text { 25th } \\
\text { Percentile }\end{array}$} & \multirow{3}{*}{$\begin{array}{l}\text { 75th } \\
\text { Percentile }\end{array}$} \\
\hline & & Lower & Upper & & & & & & & & & & & & \\
\hline & & Bound & Bound & & & & & & & & & & & & \\
\hline $\mathrm{J}$ & 47.1 & 46.1 & 48.2 & 40.3 & 38.0 & 2375.0 & 48.7 & 1.0 & 1059.0 & 1058.0 & 15.0 & 8.7 & 103.9 & 32.0 & 47.0 \\
\hline SA & 177.2 & 168.2 & 186.1 & 123.9 & 97.0 & 113976.7 & 337.6 & 1.0 & 4679.0 & 4678.0 & 112.0 & 6.8 & 59.7 & 55.0 & 167.0 \\
\hline A & 67.7 & 64.4 & 71.1 & 54.6 & 49.0 & 12974.2 & 113.9 & 1.0 & 2991.0 & 2990.0 & 46.0 & 14.1 & 286.7 & 29.0 & 75.0 \\
\hline
\end{tabular}

Table 6. The correlation coefficient (r) of $\mathrm{PM}_{2.5}$ and $\mathrm{PM}_{10}$ between the monitoring stations

\begin{tabular}{|c|c|c|c|c|c|c|c|}
\hline & & \multicolumn{2}{|l|}{$\mathrm{J}$} & \multicolumn{2}{|l|}{ SA } & \multicolumn{2}{|l|}{ A } \\
\hline & & PM10 & PM2.5 & PM10 & PM2.5 & PM10 & PM2.5 \\
\hline \multirow[t]{2}{*}{$\mathrm{J}$} & PM10 & 1 & & & & & \\
\hline & PM2.5 & $0.583^{* *}$ & 1 & & & & \\
\hline \multirow[t]{2}{*}{ SA } & PM10 & $0.789^{* *}$ & $0.633^{* *}$ & 1 & & & \\
\hline & PM2.5 & $0.725^{* *}$ & $0.685^{* *}$ & $0.845^{* *}$ & 1 & & \\
\hline \multirow[t]{2}{*}{ A } & PM10 & 0.391 & 0.180 & $0.554^{* *}$ & 0.235 & 1 & \\
\hline & PM2.5 & 0.349 & 0.398 & $0.608^{* *}$ & $0.411^{*}$ & $0.798^{* *}$ & 1 \\
\hline
\end{tabular}

* Correlation is significant at the 0.05 level (two-tailed); ** Correlation is significant at the 0.01 level (two-tailed)

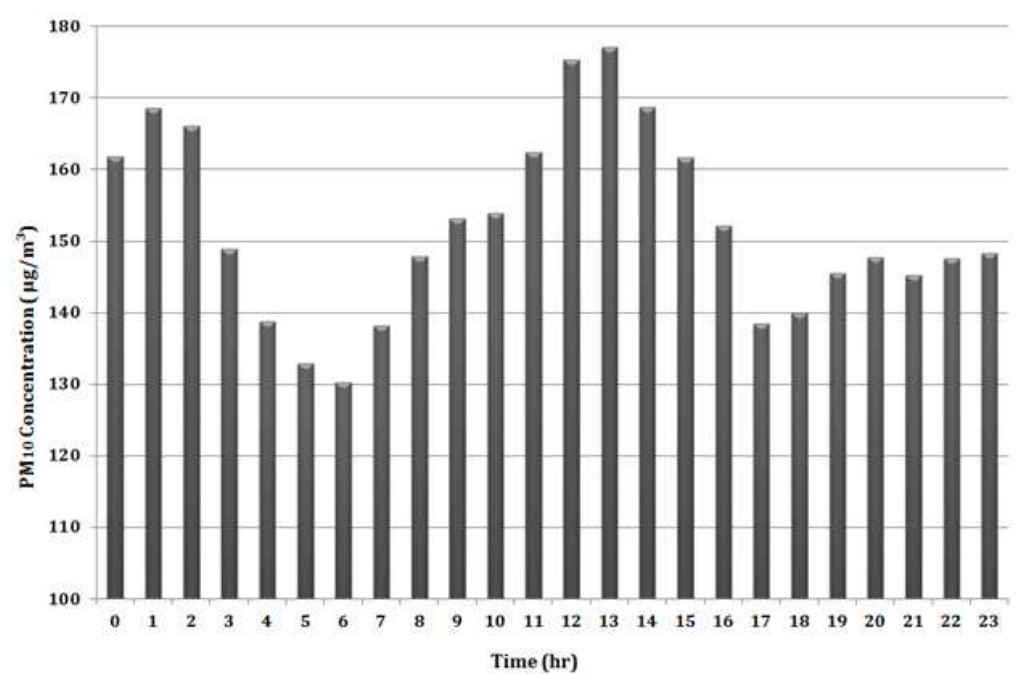

(a)

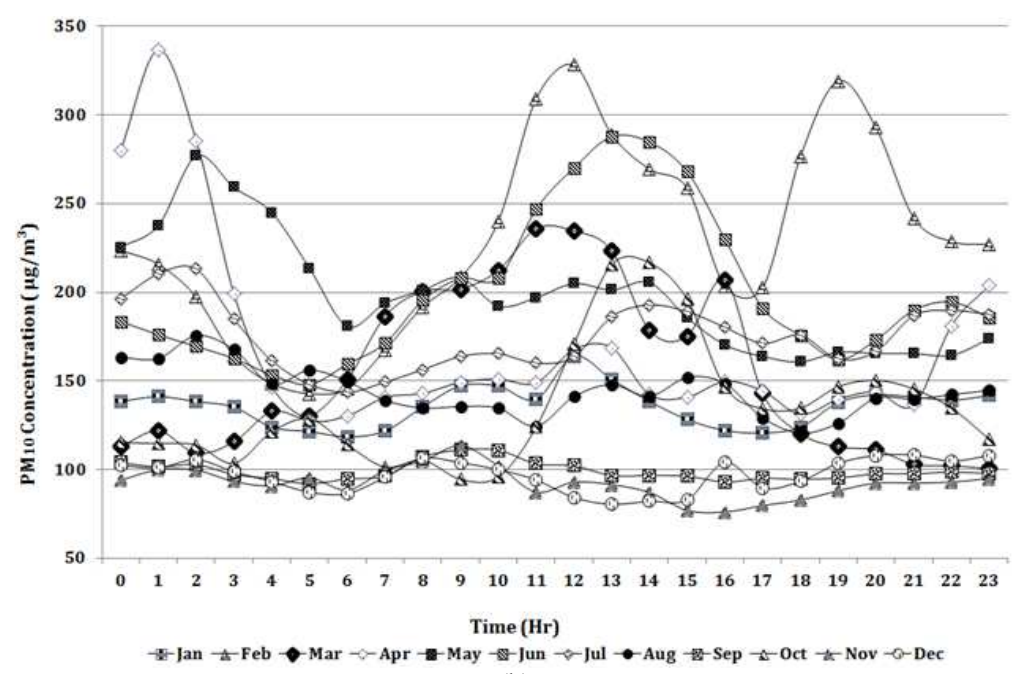

(b)

Fig. 6. Overall hourly average $\mathrm{PM}_{10}$ concentrations (a) Annual average (b) Monthly average 


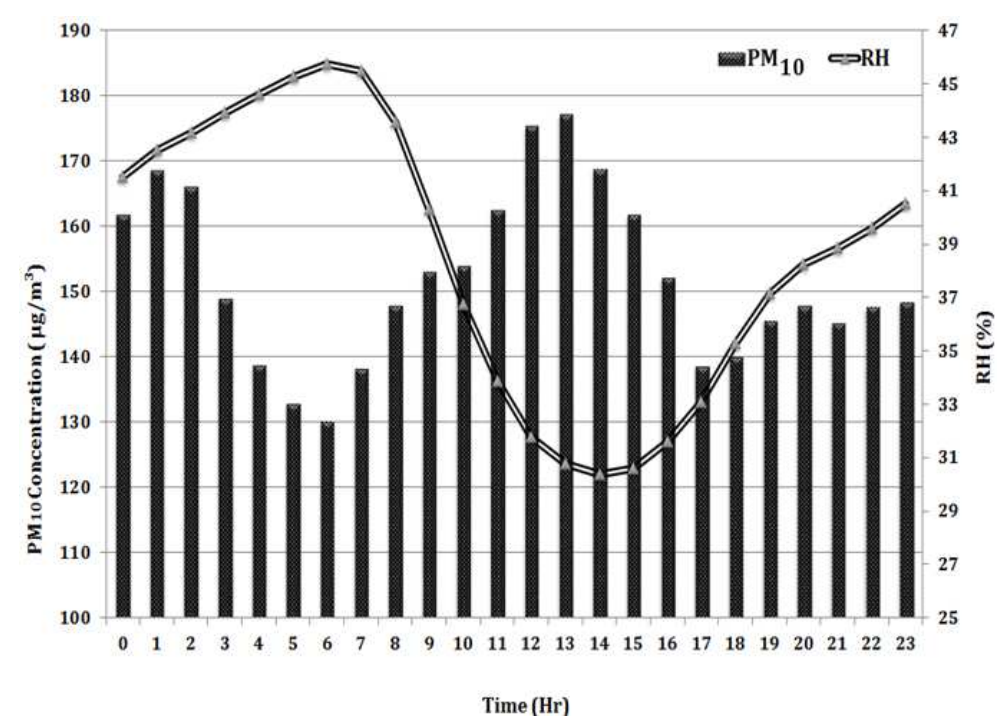

Fig. 7. Hourly average variation in relative humidity and $\mathrm{PM}_{10}$ concentration

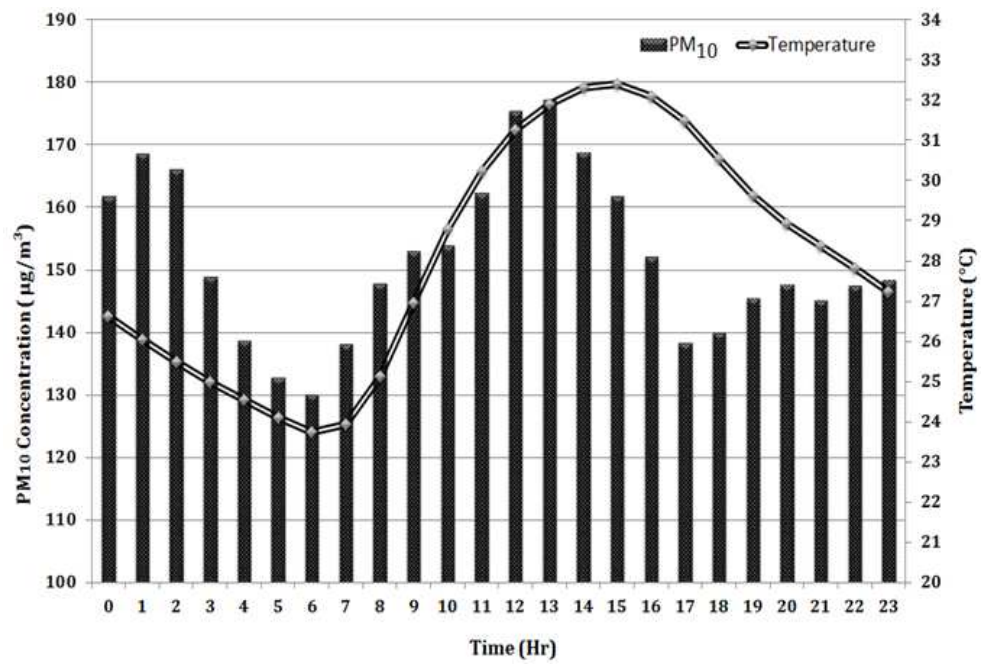

Fig. 8. Hourly average variation in temperature and $\mathrm{PM}_{10}$ concentration

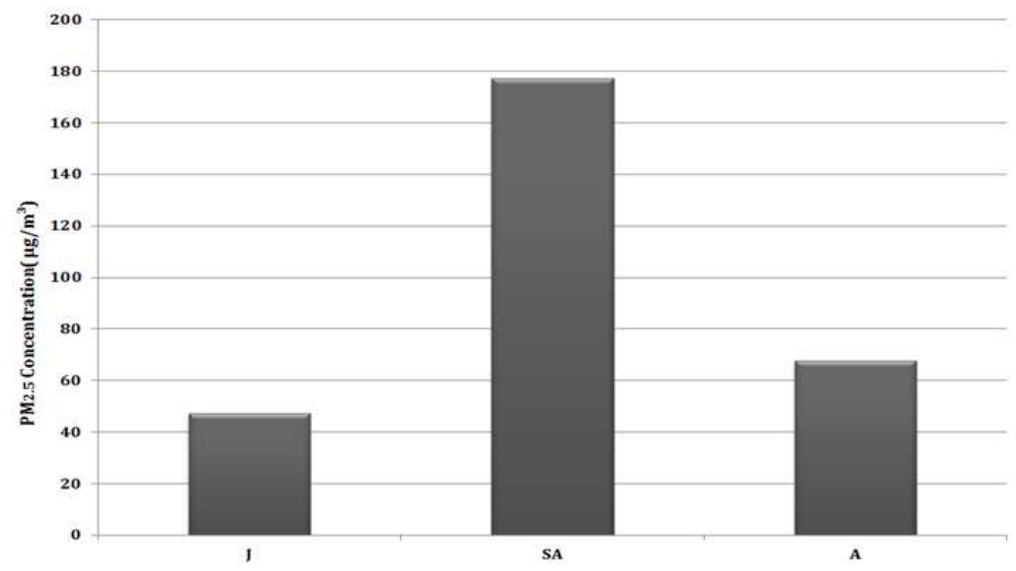

Fig. 9. The annual average concentration of $\mathrm{PM}_{2.5}$ at monitored stations 


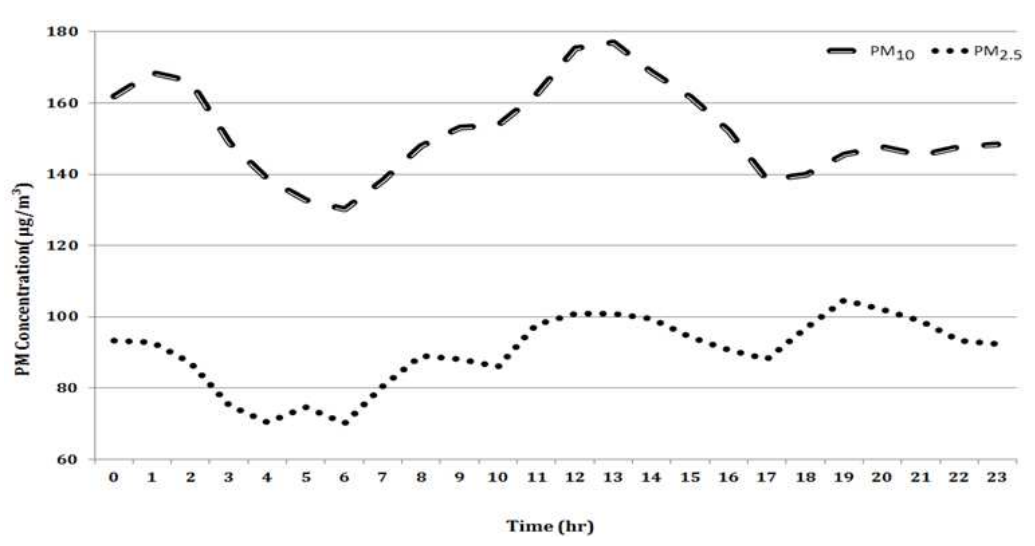

Fig. 10. Hourly averages of $\mathrm{PM}_{10}$ and $\mathrm{PM}_{2.5}$ concentrations

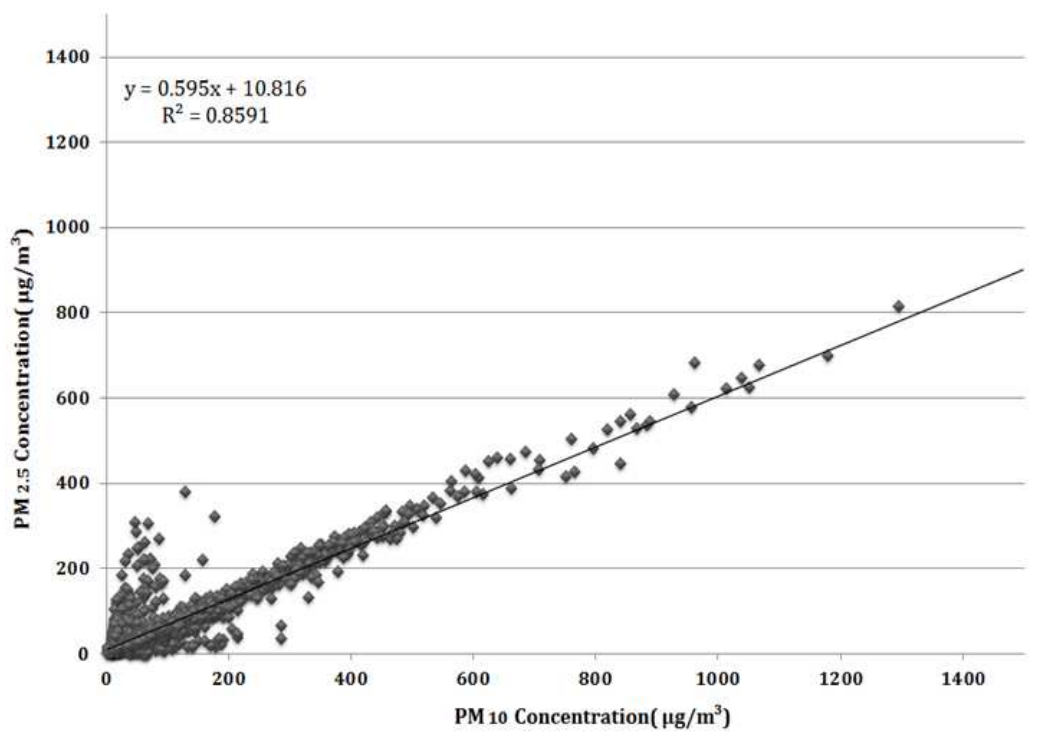

Fig. 11. Relationship between $\mathrm{PM}_{10}$ and $\mathrm{PM}_{2.5}$ at Ahmadi (A) station

According to Duan et al. (2006), high ratios (larger than the average value) are generally associated with the secondary particulate formation of species and organics, while low ratios are associated with the primary particulate formation of fugitive dust or sand dust blowing from far sources; i.e., long-distance transport. Table 6 presents the hourly analysis of correlations of the $\mathrm{PM}_{10}$ and $\mathrm{PM}_{2.5}$ pollutants. The correlation analysis showed that $\mathrm{PM}_{10}$ and $\mathrm{PM}_{2.5}$ are strongly correlated ( $r>0.4$ and reaches 0.8$)$, indicating common sources (traffic emissions or dust). The simple linear model method was employed to estimate the mathematical relationship between $\mathrm{PM}_{10}$ and $\mathrm{PM}_{2.5}$. A positive correlation between the $\mathrm{PM}_{10}$ and the $\mathrm{PM}_{2.5}$ is recognized through the following relationship (Fig. 11):

$P M_{2.5}=0.6 P M_{10}+10.8$
The value of $R^{2}$ for this relationship was 0.86 with a significant correlation coefficient of $r=0.8$ :

- Correlation is significant at the 0.05 level (twotailed)

- Correlation is significant at the 0.01 level (twotailed)

\section{Elemental Concentration in $P M_{10}$}

The elements were categorized into two groups; namely, anthropogenic activity and typical crustal elements. Table 7 shows the concentration of 15 identified elements in the $\mathrm{PM}_{10}$ samples. Al-Awadhi and Al-Shuaibi (2013) determined the elemental composition of Kuwait top sediments through the analysis of 184 top surface sediment samples collected from various existing aeolian sediments found across the Kuwaiti desert. The calculated ratios of the average crustal elements in the 
$\mathrm{PM}_{10}$ sample to crustal elements in the background surface sediment of Kuwait for $\mathrm{Ca}, \mathrm{Al}, \mathrm{Fe}$ and $\mathrm{Mg}$ ranged from 0.2 to 0.4 , while for $\mathrm{Na}$ and $\mathrm{K}$ the ratios were found to be 16.3 and 6.6 , respectively. This implies that the main source of fine particulate pollution at the urban sites could be from traffic and industrial sources with partial contributions from dust fallout. Average concentrations of the indicator elements associated with an anthropogenic activity that come primarily from industrial sources; i.e., $\mathrm{Pb}, \mathrm{Cu}$, $\mathrm{Co}, \mathrm{Cd}$ and $\mathrm{Zn}$, were 2.4, 12.9, 14.6, 42.6 and 156.2 times higher than corresponding sediment background values (measured from local aeolian sediments), respectively. The average concentrations of $\mathrm{Cr}, \mathrm{Ni}$ and $\mathrm{V}$ were found to be 80,70 and $60 \%$ less than their corresponding sediment background values, respectively. This may lead to the fact that most of the pollutants in the $\mathrm{PM}_{10}$ samples are produced from anthropogenic sources.

\section{Enrichment Factor Analysis}

A cluster analysis using average linkage clustering was performed on the standardized elemental content of $15 \mathrm{PM}_{10}$ data with the help of a Statistics Toolbox function (Fig. 12). Figure 12 displays four clusters at a level around 1.5: (1) Co-Cr-Be-Cd-V-Pb-Ni-Mn-Cu; (2) $\mathrm{Zn}-\mathrm{Mg}-\mathrm{K}$; (3) Fe-Ca-Al; and (4) Na. The analysis shows that clusters 1 and 2 are linked at a higher level $(\sim 2)$, potentially pointing to a common source, while the large separation of $\mathrm{Na}$ in cluster 4 suggests that $\mathrm{Na}$ might not share the same source as the other elements. Accordingly, this study uses $\mathrm{Na}$ as a reference element. To calculate the Enrichment Factors (EFs) for the various elements in the $\mathrm{PM}_{10}$ samples, the average concentration of $\mathrm{Na}$ in the Kuwait sediment is used as the reference element baseline $\left(B_{r e f}\right)$, while the average content of each element in the samples is selected as that element's baseline $\left(B_{n}\right)$. Table 8 lists the EFs for 10 elements identified in the $\mathrm{PM}_{10}$ samples. Table 8 indicates that the mean EFs increases in the following order: $\mathrm{Cr}, \mathrm{Ni}, \mathrm{V}, \mathrm{Fe}, \mathrm{Mn}$, $\mathrm{Pb}, \mathrm{Cd}, \mathrm{Cu}$, $\mathrm{Co}$ and $\mathrm{Zn}$., while only $\mathrm{Cu}, \mathrm{Co}$ and $\mathrm{Zn}$, have mean EFs higher or equal than 2.

The EF helps to identify which elements may have originated from human activities as opposed to natural processes and to assess the degree of this anthropogenic influence. Based on specific EF range, Table 9 presents

five contamination categories (Sutherland, 2000; Loska and Wiechuya, 2003). Usually, an EF of 10 and above (high level of enrichment) indicates an anthropogenic origin (Lee et al., 1994; Liu et al., 2003; Balasubramanian and Qian, 2004; Meza-Figueroa et al., 2007). Thus, $\mathrm{Co}, \mathrm{Cu}$ and $\mathrm{Zn}$ in the $\mathrm{PM}_{10}$ samples, can be attributed mainly to anthropogenic activity.

Table 7. Comparison between elemental contents in soils of Kuwait and $\mathrm{PM}_{10}$ samples collected in Kuwait $(\mathrm{mg} / \mathrm{kg})$

\begin{tabular}{llll}
\hline Metals & $\mathrm{PM}_{10}$ sample & Background value & Ratio \\
\hline $\mathrm{Fe}$ & $1,610.30$ & $4,115.70$ & 0.39 \\
$\mathrm{Al}$ & $2,209.20$ & $5,469.20$ & 0.40 \\
$\mathrm{Mn}$ & 41.20 & 119.60 & 0.34 \\
$\mathrm{Zn}$ & $2,868.60$ & 18.35 & 156.30 \\
$\mathrm{~V}$ & 7.90 & 19.10 & 0.41 \\
$\mathrm{Na}$ & $14,972.10$ & 915.12 & 16.36 \\
$\mathrm{~K}$ & $4,159.90$ & 630.20 & 6.60 \\
$\mathrm{Cd}$ & 17.95 & 0.42 & 42.60 \\
$\mathrm{Mg}$ & $1,230.10$ & $4,916.10$ & 0.25 \\
$\mathrm{Co}$ & 64.40 & 4.40 & 14.66 \\
$\mathrm{Cu}$ & 362.10 & 28.05 & 12.94 \\
$\mathrm{Ni}$ & 7.72 & 25.40 & 0.30 \\
$\mathrm{Cr}$ & 5.50 & 24.90 & 0.22 \\
$\mathrm{Ca}$ & $6,196.30$ & $29,707.10$ & 0.21 \\
$\mathrm{~Pb}$ & 12.67 & 5.21 & 2.42 \\
\hline
\end{tabular}

Table 8. Enrichment factors for elements in $\mathrm{PM}_{10}$ in Kuwait

\begin{tabular}{llll}
\hline & Enrichment Factor & \\
& - & Max & Ave \\
\hline $\mathrm{Flements}$ & Min & 0.94 & 0.19 \\
$\mathrm{Fe}$ & 0.003 & 0.58 & 0.22 \\
$\mathrm{Zn}$ & 0.046 & 33.53 & 9.19 \\
$\mathrm{~V}$ & 2.29 & 0.44 & 0.18 \\
$\mathrm{Cd}$ & 0.057 & 4.98 & 1.96 \\
$\mathrm{Co}$ & 0.006 & 71.91 & 8.15 \\
$\mathrm{Cu}$ & 0.001 & 29.95 & 5.90 \\
$\mathrm{Ni}$ & 0.10 & 0.71 & 0.13 \\
$\mathrm{Cr}$ & 0 & 0.41 & 0.09 \\
$\mathrm{~Pb}$ & 0 & 3.14 & 0.75 \\
\hline
\end{tabular}

Table 9. Contamination categories based on EF values

\begin{tabular}{ll}
\hline Enrichment factor (EF) & Comment \\
\hline $\mathrm{EF}<2$ & Deficiency to minimal enrichment \\
$\mathrm{EF}=2-5$ & Moderate enrichment \\
$\mathrm{EF}=5-20$ & Significant enrichment \\
$\mathrm{EF}=20-40$ & Very high enrichment \\
$\mathrm{EF}>40$ & Extremely high enrichment \\
\hline
\end{tabular}

Table 10. Gross mineralogy (XRD) of the $\mathrm{PM}_{10}$ samples (\%)

\begin{tabular}{llllllllll}
\hline Site/ & & & & & & & & \\
Sample No. & Calcite & Quartz & Rutile & Orthoclase & Albite & Dolomite & Kamacite & Halite & Braunite \\
\hline F (S1) & 16.9 & 12.3 & 20.1 & - & - & 23.6 & - & - & 13.6 \\
MU (S2) & 32.6 & 11.3 & 15.6 & - & - & 20.0 & 10.9 & 9.6 & - \\
A (S3) & 40.1 & 18.1 & - & 9.6 & 9.5 & 16.0 & - & - & - \\
Ave & 29.9 & 13.9 & 17.9 & 9.6 & 9.5 & 19.9 & 10.9 & 9.6 & 13.6 \\
\hline
\end{tabular}




\begin{tabular}{lc} 
Table 11. TPH concentrations in the PM $_{10}$ samples & \\
\hline Site & TPH $(\mu \mathrm{g} /$ filter $)$ \\
\hline MU & 238 \\
J & 189 \\
SA & 205 \\
SH & 197 \\
R & 274 \\
A & 284 \\
F & 246 \\
AS & 296 \\
Average & 241 \\
\hline
\end{tabular}

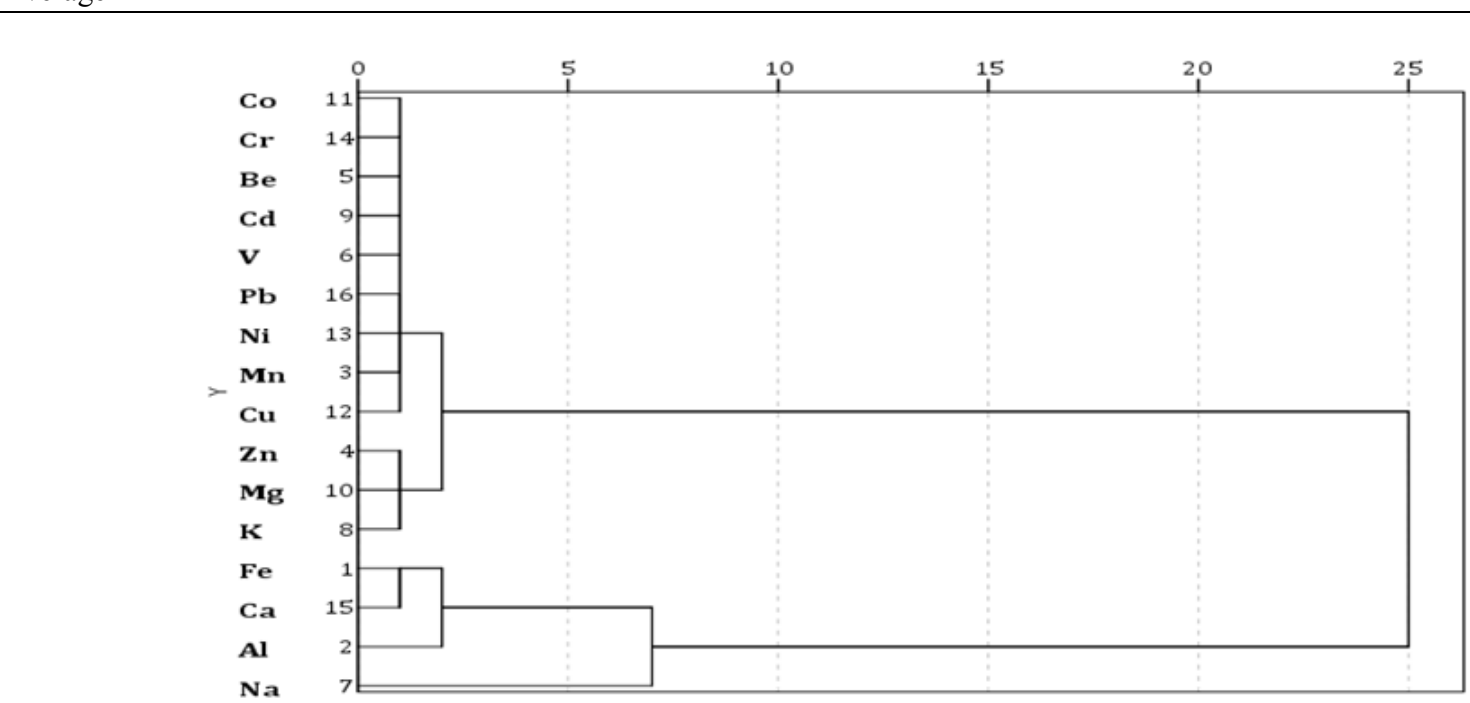

Fig. 12. Hierarchical dendogram for measured pollutants in $\mathrm{PM}_{10}$ (the distances reflect the degree of correlation between different elements)
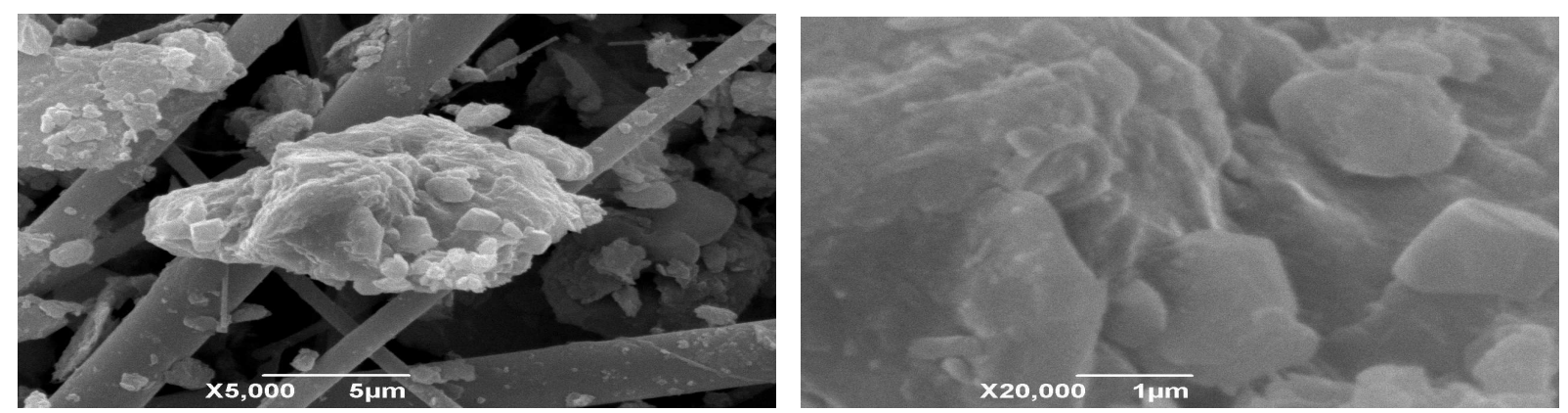

Fig. 13. SEM images of $\mathrm{PM}_{10}$ collected at station $\mathrm{A}$; showing both grain sizes and morphology of the particulate matter

The $\mathrm{PM}_{10}$ samples are moderately contaminated by $\mathrm{Pb}$ and $\mathrm{Cd}$, since their maximum $\mathrm{EF}$ values range between 2 and 5 . However, the $\mathrm{PM}_{10}$ samples are highly contaminated by $\mathrm{Zn}$ and $\mathrm{Cu}$, since their maximum $\mathrm{EF}$ values fell between 20 and 40, while Co had a maximum EF of more than 40, thus indicating extremely high contamination. $\mathrm{Cu}$ and $\mathrm{Pb}$ can be emitted from fossil fuel combustion, metal processing, tires abrasion, brake linings, exhaust catalysts, road pavement and corrosion of galvanized protection barriers (Al-Awadhi and Al-Awadhi, 2013). The maximum EFs of other elements were low, indicating that these elements are insignificant contaminants.

\section{Mineralogical and SEM Analysis}

Mineralogical analysis of three $\mathrm{PM}_{10}$ samples showed that all samples consisted of calcite $(29.9 \%$ on average), dolomite (19.9\% on average) and quartz $(13.9 \%$ on average) minerals, with an appreciable amount of illite, dolomite and albite and rare percentages of orthoclase (Table 10). Khalaf (1989) and Al-Awadhi and Al-Shuaibi (2013) found 
appreciable percentages of calcite and quartz within fine size fractions of surface sediments and dust samples collected in Kuwait. Accordingly, the genesis and composition of the local dust and aeolian sand should have a direct influence on the mineralogical composition of $\mathrm{PM}_{10}$.

The grain size and morphological characteristics of one of the 20 collected $\mathrm{PM}_{10}$ samples, as observed by the SEM, is illustrated in Fig. 13. The figure distinctly shows different morphological structures and sizes of the grains. Most of the samples generally contain quartz, calcite, dolomite and clay particles. A few samples contain gypsum and feldspars. Fibrous cyan bacteria occur in most samples as well as some pollen grains. Clay particles are commonly less than $0.5 \mu \mathrm{m}$ in size, while the other minerals (i.e., quartz, calcite, dolomite, gypsum and feldspars) occur as grains or clustered grains of more than $4 \mu \mathrm{m}$ in size. No significant difference in the sample composition was recognized; however, samples from Ahmadi (A) and Mutla (M) stations, near north and south oil fields, respectively, are relatively rich in carbonates.

\section{Total Petroleum Hydrocarbon (TPH) Analysis}

An attempt was made to investigate the toxicity of the persistent organic contaminants in the $\mathrm{PM}_{10}$ via measuring the TPH at 8 monitoring stations. The qualitative concentrations of TPHs in the $\mathrm{PM}_{10}$ samples are presented in Table 11. The areas located near oil field/industrial area exhibits higher $\mathrm{PM}_{10}$ contaminations of TPH than in other areas. Higher mean TPHs concentrations are recorded in AS $(296 \mu \mathrm{g} /$ filter $), \mathrm{F}$ and A stations, while lower mean concentration is recorded in $\mathrm{J}$ station $(189 \mu \mathrm{g} /$ filter $)$. The elevated mean concentration of TPH in $\mathrm{PM}_{10}$ samples at $\mathrm{R}$ station may be associated with high emission rate due to vehicle movements in this area. Such finding may indicate that while the traffic remains a main source of $\mathrm{PM}_{10}$ pollution in the residential areas in Kuwait, petrochemical industries and oil fields/refineries are also possible sources in the vicinity of these areas.

\section{Air Quality Index (AQI)}

Figure 14 illustrates the results of AQI values for the daily average of $\mathrm{PM}_{10}$ concentrations for the period from March 2014 to February 2015 at the AQM stations. On average, 39.6 and $53.64 \%$ of the daily calculated AQI values for $\mathrm{PM}_{10}$ concentrations are categorized as "good" and "moderate", respectively. The moderate values were more abundant in areas with heavy traffic, such as SH, MA and $\mathrm{S}$, as well as in AS, which is located downwind of the Shuaiba industrial area. In the winter season, $43 \%$ of the daily average data was categorized as "moderate", while in the summer season, this percentage increased to $80 \%$ (Fig. 15). The percentage of elevated values in the "moderate" category in summer, in some cases, may be directly associated with regular dust phenomenon during this season; roadside dust may be another possible source.

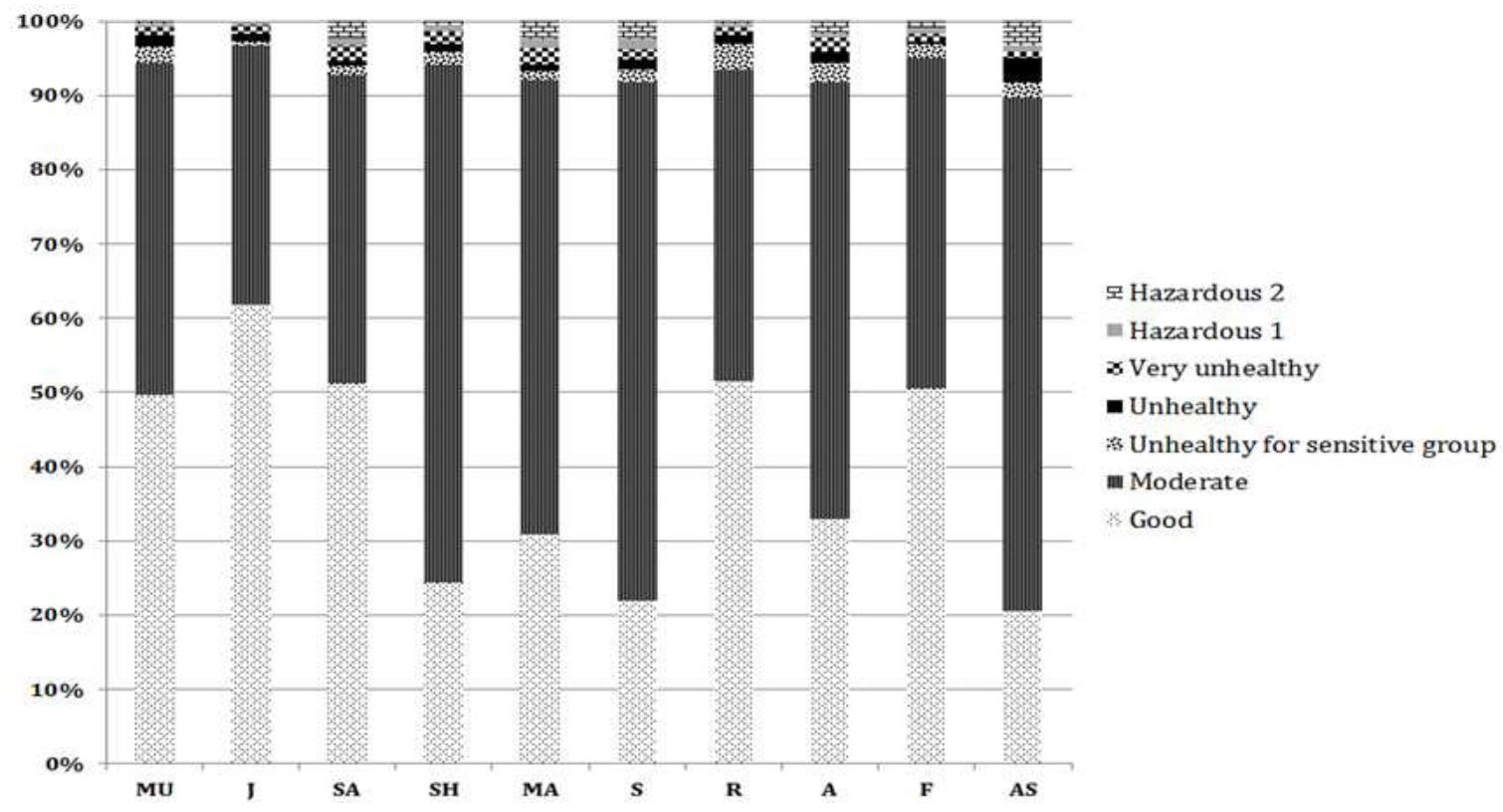

Fig. 14. Annual AQI for $\mathrm{PM}_{10}$ concentrations at the 10 stations 


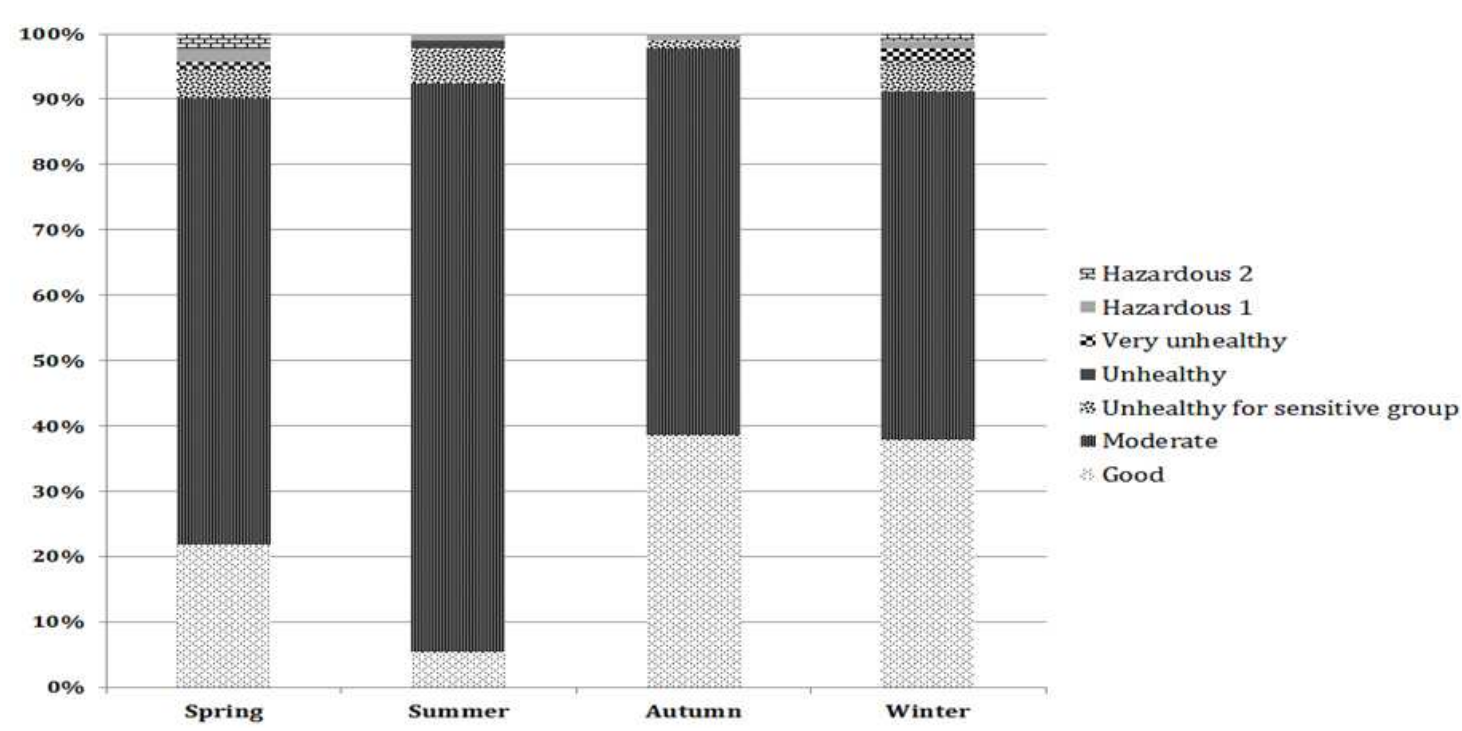

Fig. 15. Seasonal AQI for $\mathrm{PM}_{10}$ in Kuwait

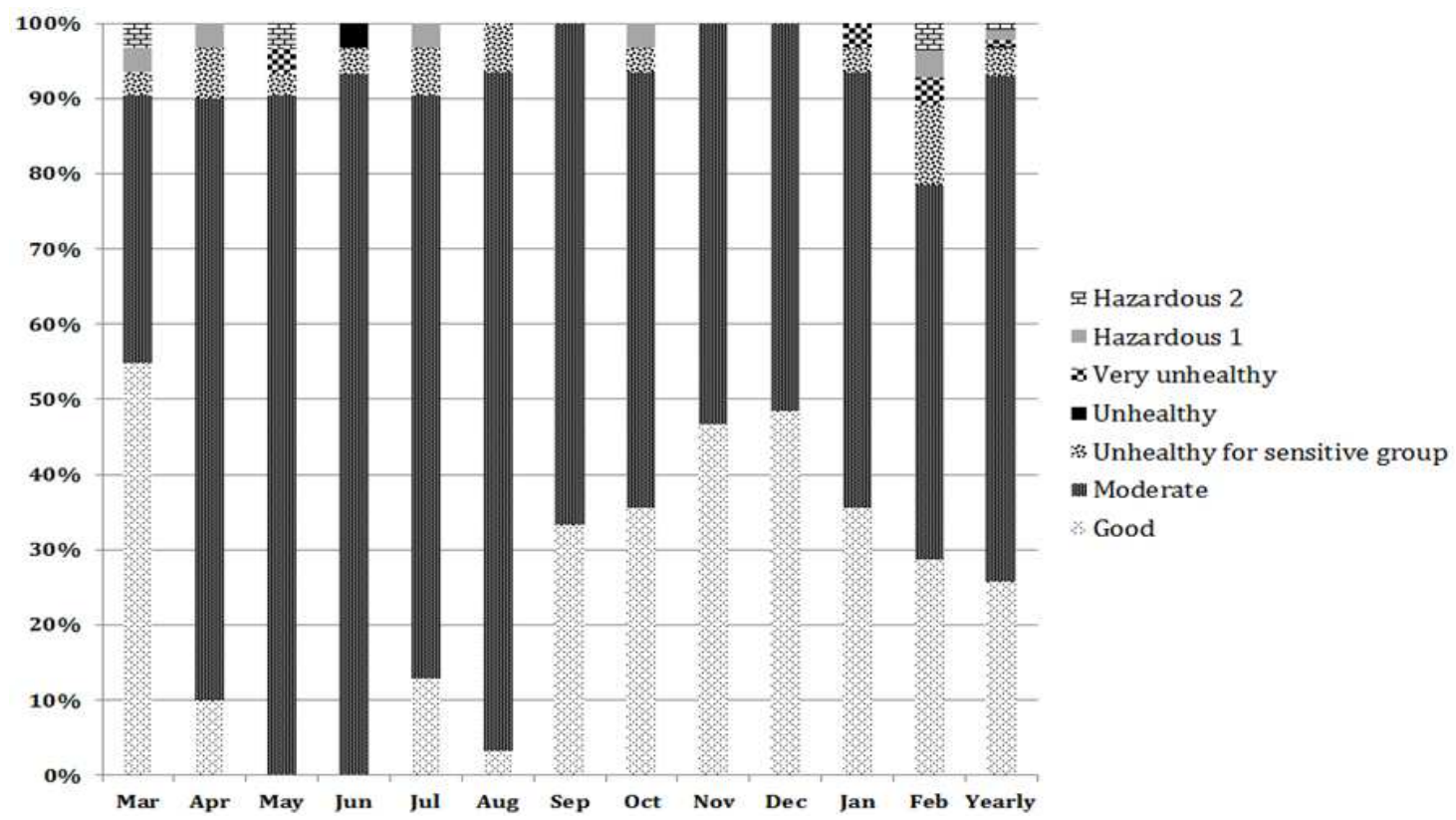

Fig. 16. Monthly AQI for $\mathrm{PM}_{10}$ in Kuwait

The overall monthly assessment of the $\mathrm{PM}_{10}$ in Kuwait (Fig. 16), indicates that about $7.3 \%$ of AQI values are categorized as "unhealthy" and "very unhealthy", while 1.3 and $3.8 \%$ of AQI values are categorized as "hazardous 1 " and "hazardous 2", respectively. This indicates that $\mathrm{PM}_{10}$ is a worrying pollutant in the cities of Kuwait.

\section{Conclusion}

In this study, one-year $\mathrm{PM}_{10}$ and $\mathrm{PM}_{2.5}$ data set (March 2014 to February 2015) was evaluated and analyzed for different urban areas of Kuwait. In some areas, $68.4 \%$ of daily mean values of $\mathrm{PM}_{10}$ exceeded the Kuwait EPA permissible limit $\left(350 \mu \mathrm{gm}^{3}\right)$, while the average concentration of $\mathrm{PM}_{2.5}$ is found to be 9.7 times more than the annual US NAAQS standard (10 $\left.\mu \mathrm{g} / \mathrm{m}^{3}\right)$. Beside the traffic emissions, the prevailing northwesterly winds are likely to influence the diffusion of $\mathrm{PM}_{10} / \mathrm{PM}_{2.5}$ concentrations generated from the oil fields and industrial areas, towards the urban areas. The high percentages of calcite and the appreciable amount of quartz found in the $\mathrm{PM}_{10}$ samples may indicate that dust fallout and the roadside dust are other possible sources. A number of toxic 
metal were noticeably enriched in the $\mathrm{PM}_{10}$ samples due to anthropogenic activities. Enrichment factor analysis revealed that $\mathrm{PM}_{10}$ being contaminated by the following metals with an increase in the order of $\mathrm{Cr}$, $\mathrm{Ni}, \mathrm{V}, \mathrm{Fe}, \mathrm{Mn}, \mathrm{Pb}, \mathrm{Cd}, \mathrm{Cu}, \mathrm{Co}$ and $\mathrm{Zn}$. The TPH results also show relatively higher values in $\mathrm{PM}_{10}$ samples collected near oil industrial areas than in other areas.

Seasonal variability of PM levels was clearly noticed. In winter season, lower concentrations in PM levels is attributed to low wind velocity that likely results in lower concentrations of re-suspended roadside dust particles, while higher concentrations in PM levels during summer season are accounted to the effects of frequent dust storms. However, in some summer days, under certain circumstances when there is no dust storm, the PM levels were likely lower due to either perfect atmospheric mixing or reduced number of the vehicles on the road. The analysis of hourly variation in the $\mathrm{PM}_{10}$ concentrations during the day, also, showed elevation and reduction in the level with respect to the temperature and humidity, respectively.

Although site-to-site differences in $\mathrm{PM}_{10}$ and $\mathrm{PM}_{2.5}$ were found, a strong relationship between them was observed, this may indicate similar source origination from either local traffic or industrial sources. In general, the result of AQI shows that $\mathrm{PM}_{10}$ levels can be characterized as "moderate". With such unappreciated levels of $\mathrm{PM}_{10}$ as well $\mathrm{PM}_{2.5}$ pollutants in Kuwait's urban areas, mitigations should be implemented to minimize emission rate and health and environmental impact assessment study is recommended to investigate long-term impacts. To decrease PM emission rates, concerned parties (Kuwait EPA) must regulate car emissions and force $\mathrm{PM}_{10}$ and $\mathrm{PM}_{2.5}$ regulations governing emissions from industries such as refineries, cement, ceramic and stone factories.

\section{Acknowledgment}

This work was supported by Kuwait University Research Grant No. [SE02/14]. This work was also supported by Science Analytical Facilities (SAF) and National Unit for Environmental Research and Services (NUERS-Project No. SRUL01/13) at Kuwait University. The authors gratefully acknowledge Kuwait Environment Public Authority (K-EPA) for providing PM data and PM samples. The authors also highly acknowledge the analysis support provided by Ms. Shahrzad Gashsi.

\section{Author's Contributions}

Jasem M. Al-Awadhi: Participated in data collection and analysis and contributed to the writing of the manuscript (Percentage of contribution 70\%).
Anwar B. Al-Helal: Participated in data-analysis and contributed to the reviewing of the manuscript (Percentage of contribution 30\%).

\section{Ethics}

This article is original and contains unpublished material. The corresponding author confirms that all of the other authors have read and approved the manuscript and no ethical issues involved.

\section{References}

Addo, M.A., E.O. Darko, C. Gordon, B.J.B. Nyarko and J.K. Gbadago, 2012. Heavy metal concentrations in road deposited dust at ketu-south district. Ghana. Int. J. Sci. Technol., 2: 28-39.

Al-Awadhi, F.A. and S.A. Al-Awadhi, 2006. Spatialtemporal model for ambient air pollutants in the state of Kuwait. Environmetrics, 17: 739-752. DOI: 10.1002/env.791

Al-Awadhi, J.M. and A.A. AlShuaibi, 2013. Dust fallout in kuwait city: Deposition and characterization. Sci. Total Environ., 461: 139-148. DOI: 10.1016/j.scitotenv.2013.03.052

Al-Basri, A., 1993. Dust Phenomena and their environmental impacts in Kuwait. MSc Thesis, Arabian Gulf University.

Al-Hajraf, S., D. Al-Ajmi, A. Khan, H. Tang and A. Wahner et al., 2005. Air quality assessment of Ali Sabah Al-Salem urban community. Kuwait Ins. Scient. Res. (KISR).

Al-Salem, S.M. and A.R. Khan, 2008. Comparative assessment of ambient air quality in two urban areas adjacent to petroleum downstream/upstream facilities in Kuwait. Brazilian J. Chem. Eng., 25: 683-696. DOI: 10.1590/S0104-66322008000400006

Al-Shayji, K., H.M. Lababidi, D. Al-Rushoud and H. AlAdwani, 2008. Development of a fuzzy air quality performance indicator. Kuwait J. Sci. Eng., 35: 10-26.

AMAP, 1997. Arctic pollution issues: A state of the arctic environment report. Arctic Monitoring and Assessment Programme (AMAP), Olsen and Olsen Academic Publishers, Oslo, Norway.

Balasubramanian, R. and W.B. Qian, 2004. Characterization and source identification of airborne trace metals in Singapore. J. Environ. Monit., 6: 813-818. DOI: 10.1039/B407523D

Dannecker, W.B., B.H. Schroder and S.T. Stechmann, 1990. Organic and inorganic substances in highway tunnel exhaust air. Sci. Total Environ., 93: 293-300. DOI: 10.1016/0048-9697(90)90119-F

Donaldson, K. and W. MacNee, 1998. The mechanism of lung injury caused by $\mathrm{PM}_{10}$. J. Sci. Technol., 1: 10-16. DOI: 10.1039/9781847550095-00021 
Duan, F.K., K.B. He, Y.L. Ma, F.M. Yang and X.C. $\mathrm{Yu}$ et al., 2006. Concentration and chemical characteristics of $\mathrm{PM}_{2.5}$ in Beijing, China: 2001-2002. Sci. Environ., 355: 264-275. DOI: $10.1016 /$ j.scitotenv.2005.03.001

Goyer, R.A., 1996. Results of lead research: Prenatal exposure and neurological consequences. Environ. Health Perspectives, 104: 1050-1054.

Khalaf, F.I., 1989. Desertification and Aeolian processes in the Kuwait Desert. J. Arid Environ., 16: $125-145$.

Khan, A. and S. Al-Salem, 2007. Seasonal variation effect on airborne pollutants in an urban area in the state of Kuwait. J. Environ. Res. Dev., 1: 215-218.

Lee, D.S., J.A. Garland and A.A. Fox, 1994. Atmospheric concentrations of trace elements in urban areas of the United Kingdom. Atmospheric Environ., 28: 2691-2713.

DOI: $10.1016 / 1352-2310(94) 90442-1$

Meza-Figueroa, D., M.D.1. O-Villanueva and M.L.D.1. Parra, 2007. Heavy metal distribution in dust from elementary schools in Hermosillo, Sonora, México. Atmospheric Environ., 41: 276-288.

DOI: 10.1016/j.atmosenv.2006.08.034

KEPA, 2014. Pollution load assessment. Kuwait Environmental Action Program. Published by Kuwait Environment Public Authority (K-EAP) in collaboration with the World Bank, Kuwait.

SEP, 2003. Monitoring and Method of Air and Waste Gases 4th Edn., Environment Science Press, Beijing, China, pp: 9.
Liu, Q.T., M.L. Diamond, S.E. Gingrich, J.M. Ondov and P. Maciejczyk et al., 2003. Accumulation of metals, trace elements and semi-volatile organic compounds on exterior window surfaces in baltimore. Environ. Pollut., 122: 51-61. DOI: 10.1016/S0269-7491(02)00286-5

Loska, K. and D. Wiechula, 2003. Application of principal component analysis for the estimation of source of heavy metal contamination in surface sediments from the Rybnik Reservoir. Chemosphere, 51: 723-733. DOI: $10.1016 / \mathrm{S} 0045-6535(03) 00187-5$

Singh, S.R., 2001. Concentration of fine silica and heavy metals in respirable suspended particulate matter small-scale foundries in Chandigarh. J. Occup. Environ. Med., 5: 196-200.

Sutherland, R.A., 2000. Bed sediment-associated trace metals in an urban stream. Oahu, Hawaii. Environ. Geol., 39: 611-627. DOI: 10.1007/s002540050473

USEPA, 2006. Guideline for reporting of daily air quality-Air Quality Index (AQI). Office of Air Quality Planning and Standards, Research Triangle Park, NC 27711, USA.

USEPA, 1999a. National air toxics program, the integrated urban strategy. United States Environm, Protection Agency's, Federal Reg.

USEPA, 1999b. Compendium of methods for the determination of inorganic compounds in ambient air. Compendium of Method IO-3.1, EPA/625/R96/010a. 